\title{
Uterine response to progesterone in prepubertal gilts
}

\author{
P. G. Groothuis ${ }^{1 *}$, R. M. Blair ${ }^{1 \dagger}$, R. C. M. Simmen ${ }^{2}$, J. L. Vallet ${ }^{3}$, \\ D. M. Grieger ${ }^{1}$ and D. L. Davis ${ }^{1 \ddagger}$
}

${ }^{1}$ Department of Animal Sciences and Industry, Kansas State University, Manhattan, KS; ${ }^{2}$ Department of
Animal Science, University of Florida, Gainesville, FL; and ${ }^{3}$ US Department of Agriculture, Agricultural
Research Service, Roman L. Hruska, US Meat Animal Research Center, Clay Center, NE

During early pregnancy, progesterone stimulates the secretion of proteins and other molecules that support the developing conceptus. Some gilts are able to support conceptus development as early as 110 days of age. The objective of this study was to evaluate the onset of responsiveness of the prepubertal uterus to progesterone. Thirty gilts were assigned to receive $2.2 \mathrm{mg}$ progesterone $\mathrm{kg}^{-1}$ body mass per day or corn oil daily for 14 days starting at $6,46,76,106$, and 136 days of age. Hysterectomies were performed the day after the last treatment of progesterone, and the uterine horns were weighed and flushed with sterile saline $(0.85 \% \mathrm{NaCl})$. Recovered flushings were analysed for total luminal protein, retinol binding protein, uteroferrin, prostaglandin $\mathrm{E}$ and prostaglandin $\mathrm{F}$. An interaction between age and progesterone occurred for uterine wet mass $(P<0.001)$. Progesterone did not affect the uterine mass of gilts that underwent hysterectomy at 20 days of age, but did increase the uterine mass $(P<0.05)$ in other age groups. Progesterone increased $(P<0.01)$ the amount of total luminal protein in all but the youngest gilts. An increase in the amounts of retinol binding protein and uteroferrin $(P<0.001)$ by progesterone was first observed in 90-day-old gilts. Prostaglandins exhibited a different age-related pattern. The amount of prostaglandin $\mathrm{E}$ was increased $(P<0.001)$ by progesterone treatment in gilts aged 90-150 days, with a greater $(P<0.05)$ response at 120 days than at 90 days old. The response at 150 days old decreased $(P<0.05)$ to that observed at day 90 . The response of prostaglandin $F$ to progesterone followed a similar age-related pattern. Therefore, uterine responsiveness to progesterone develops between 20 and 90 days after birth, and uterine mass responds earlier than the secretory responses measured in our study.

\section{Introduction}

The development of the neonatal uterus in the pig is limited and the endometrium consists of a poorly differentiated mesenchyme (Spencer et al. 1993a, b). The formation of uterine glands is initiated during the first week of postnatal life, and by 30 days of age the overall histoarchitectural characteristics of adult females are present but not fully developed (Bal and Getty, 1970).

Although puberty normally occurs after 150 days of age for most domestic breeds of pig, gilts can be induced to ovulate and pregnancies can be initiated at 90-120 days of age (Casida, 1935; Dziuk and Gehlbach, 1966; Shaw et al., 1970; Neville

\footnotetext{
*Present address: Department of Pathology, University Hospital Maastricht Academic Hospital Maastricht. The Netherlands.

†Present address: Pennington Biomedical Research Center, Baton Rouge, LA 70808-4124, USA.

${ }^{\ddagger}$ Correspondence.

Mention of names are necessary to report factually on available data; however, the USDA neither guarantees nor warrants the standard of the product, and the use of the same by USDA implies no approval of the product to the exclusion of others that may also be suitable.

Received 16 January 1997.
}

et al., 1971; Ellicott et al., 1973; Segal and Baker, 1973). Therefore, the gilt's uterus appears to be responsive to the hormones of pregnancy well in advance of spontaneous puberty. However, fertility is marginal for these young gilts: their corpora lutea are generally not maintained beyond the cyclic lifespan; and litter size is small for those that manage to maintain their pregnancies.

Information on uterine responses to hormones is limited for gilts that are this young. Murray and Grifo (1976) investigated the electrophoretic patterns of uterine secretory proteins of prepubertal gilts that received exogenous progesterone. Induction of specific acidic and basic protein bands was variable when the 15-day treatment period began before gilts were 126-140 days old. In addition, up until 160 days of age, electrophoresis results indicated a reduced induction of proteins compared with those observed in sexually mature gilts. As indicated by Murray and Grifo (1976), the prepubertal gilt might provide a model to study the roles of uterine secretions in pregnancy. Also, uterine traits that affect embryo survival and uterine capacity may vary during the neonatal period, as discussed by Bartol et al. (1993). 
Since the report of Murray and Grifo (1976), specific and sensitive radioimmunoassays have been developed for two of the progesterone-induced uterine proteins, retinol binding protein (RBP) (Vallet, 1994) and uteroferrin (UF) (Simmen et al., 1988). In addition to proteins, the prostaglandins are involved intimately in uterine functions. To increase our understanding of the functional capabilities of the prepubertal uterus during development, this study was performed to gain quantitative information on endometrial secretory abilities in response to progesterone. Knowledge of the maturation of regulatory pathways for progesterone in the uterus of prepubertal gilts will give further insights into uterine physiology and the ability of the uterus to support embryonic and fetal development.

\section{Materials and Methods}

\section{Animals}

Thirty crossbred gilts were assigned to one of five groups to receive either daily i.m. injections of vehicle (corn oil, $n=15$ ) or progesterone $(n=15)\left(2.2 \mathrm{mg} \mathrm{kg}^{-1}\right.$ bodymass per day) for 14 consecutive days before hysterectomy at 20,60,90, 120 and 150 days of age. The dose of and duration of treatment with progesterone were chosen based on progesterone replacement studies of gilts receiving ovariectomies after puberty (Roberts and Bazer, 1988). Six gilts (three control and three treated with progesterone) were assigned randomly to each age group. Blood samples were collected $24 \mathrm{~h}$ after the last treatment (before anaesthesia) to monitor the peripheral concentrations of progesterone and oestradiol.

\section{Tissue collection}

On the day after the last injection, laparotomies were performed on gilts under methoxyflurane inhalation anaesthesia, and the uterus was removed. Uterine horns were freed of mesometrium, blotted on paper towels and weighed. Uteri were then flushed with sterile saline $(0.85 \%(\mathrm{w} / \mathrm{v}) \mathrm{NaCl})$. Because of the large variation in uterine size in gilts of different ages and in treated versus nontreated gilts, the amount of saline used was varied: volumes used were $6 \mathrm{ml}$ for all 20-day-old gilts, $20 \mathrm{ml}$ for 60-day-old gilts and 90-day-old controls, $30 \mathrm{ml}$ for progesterone-treated 90-day-old and 120-day-old and 150-day-old control gilts, and $40 \mathrm{ml}$ for 120-day-old and 150-day-old progesterone-treated gilts. These different volumes partially offset the effects of large differences in uterine size and avoided excessive dilution of samples collected from small uteri. Proteins quantified are either the total recovered from the uterus or the amount recovered per $\mu \mathrm{g}$ total protein. The amount recovered per $\mu \mathrm{g}$ total protein reveals the specific induction of particular proteins rather than the general increase in all proteins. Uterine flushings were centrifuged at $1000 \mathrm{~g}$ for $10 \mathrm{~min}$ and stored at $-20^{\circ} \mathrm{C}$ until quantified for proteins and prostaglandins.

\section{Assays}

Serum samples were assayed for progesterone and oestradiol using Coat-a-Count assay kits (Diagnostic Products
Corporation, Los Angeles, CA) that had been previously validated for pig serum by Blair et al. (1994). The intra-assay coefficients of variation for progesterone and oestradiol were $2.8 \%$ and $7.8 \%$ and sensitivities were $5 \mathrm{pg} \mathrm{ml}^{-1}$ and $3 \mathrm{pg}$ $\mathrm{ml}^{-1}$, respectively. Total luminal protein (TLP) was estimated using the Folin-phenol reagent (Lowry ef al., 1951). Uterine flushes were radioimmunoassayed as described for RBP (Vallet, 1994), UF (Simmen et al., 1988) and prostaglandin E (PGE) (Rosenkrans et al., 1990). All samples were included in a single assay for UF, and the intra-assay coefficient of variation was $2.2 \%$ with an assay sensitivity of $5 \mathrm{ng} \mathrm{ml}^{-1}$. The intra- and interassay coefficients of variation and assay sensitivities were $12.5 \%, 14.6 \%$ and $10 \mathrm{ng} \mathrm{ml}^{-1}$ for RBP and $11.0 \%, 13.6 \%$ and $7 \mathrm{pg} \mathrm{ml}^{-1}$ for PGE.

Prostaglandin F (PGF) was assayed using procedures described by Fertel et al. (1981). Since the crossreactivities of the antibody with other related prostaglandins reported by Danet-Desnoyers et al. (1994) were less than 1\%, except for PGF $_{I \alpha}(63 \%)$, values are reported as for PGF only. Pooled samples were assayed in 5, 20, 50, 100, 150 and $200 \mu \mathrm{l}$ volumes and the displacement of radioactive PGF was parallel with the standard curve produced by adding increasing concentrations of authentic $\mathrm{PGE}_{2}$. Immunorecovery was determined by adding 10, 25, 50, 100 and $250 \mathrm{pg}$ of $\mathrm{PGF}_{1 \alpha}$ and was $98 \pm 6.3 \%$. All samples were included in a single assay for PGF, and the intra-assay coefficient of variation was $8.1 \%$. Assay sensitivity was $10 \mathrm{pg} \mathrm{ml}^{-1}$.

\section{Western blot analysis}

To verify radioimmunoassay results, western blot analyses for RBP and UF were performed using the Immuno-Blot assay kit and Mini-Trans-Blot Electrophoretic Transfer Cell Kit (BioRad, Hercules, CA). Proteins $(7-8 \mu \mathrm{g})$ from the uteri of prepubertal gilts were separated by SDS-PAGE and transferred electrophoretically on to nitrocellulose membranes (Bio-Rad). Nonspecific binding was blocked by incubation in $20 \mathrm{mmol}$ Tris $\mathrm{l}^{-1}, 500 \mathrm{mmol} \mathrm{NaCl}^{-1}$ (TBS, $\mathrm{pH} 7.5$ ), and $3 \%$ gelatin, and membranes were washed and incubated with rabbit antihuman RBP (1:200; Dako Corporation, Carpenteria, CA) or rabbit anti-UF (Simmen et al, 1988) in antibody buffer overnight at room temperature on a rocking plate.

After incubation, the membranes were washed and incubated with horseradish peroxidase-conjugated goat anti-rabbit IgG (1:3000) and avidin-labelled horseradish peroxidase (1:3000) for $2 \mathrm{~h}$ at room temperature. To visualize the proteins, the membranes were soaked in colour development buffer (Immuno-Blot assay kit, Bio-Rad).

\section{Statistical analyses}

Western blots were evaluated qualitatively. For all other data, except the amount of PGF in the uterus, the effects of treatment with progesterone were evaluated on logarithmically transformed data by least-squares analysis of variance using the General Linear Models (GLM) procedure of the Statistical Analysis System (SAS, 1982) with age, treatment, and age $\times$ treatment interactions in the model. The concentrations of PGF in control gilts and in progesterone-treated gilts at Downloaded from Bioscientifica.com at 04/26/2023 08:52:34AM 
Table 1. Steroid concentrations in the serum from control and progesterone-treated gilts ${ }^{\mathrm{a}}$

\begin{tabular}{|c|c|c|c|c|}
\hline \multirow{2}{*}{$\begin{array}{l}\text { Age at time of } \\
\text { treatment }\end{array}$} & \multicolumn{2}{|c|}{ Oestradiol $\left(\mathrm{pg} \mathrm{ml}^{-1}\right)$} & \multicolumn{2}{|c|}{ Progesterone ( $\mathrm{ng} \mathrm{ml}^{-1}$ ) } \\
\hline & Control & Progesterone-treated & Control & Progesterone-treated \\
\hline 20 & $5.6 \pm 0.7$ & $3.9 \pm 3.1$ & $0.80 \pm 9.4$ & $8.1 \pm 7.1$ \\
\hline 60 & $2.2 \pm \quad 0.3$ & $3.9 \pm 1.0$ & $0.41 \pm 0.2$ & $17.9 \pm 19.3$ \\
\hline 90 & $6.6 \pm 1.9$ & $6.5 \pm 2.5$ & $0.44 \pm 0.2$ & $8.9 \pm 2.6$ \\
\hline 120 & $53.0 \pm 81.8$ & $5.9 \pm 1.3$ & $0.46 \pm 0.4$ & $10.8 \pm 5.0$ \\
\hline 150 & $5.8 \pm 1.9$ & $6.3 \pm 1.5$ & $0.36 \pm 0.01$ & $19.9 \pm 9.6$ \\
\hline All ages & $14.7 \pm 36.8$ & $5.4 \pm 2.0$ & $0.50 \pm 0.30$ & $13.1 \pm 10.1^{b}$ \\
\hline
\end{tabular}

aBlood was collected $24 \mathrm{~h}$ after the last injection of progesterone or vehicle (controls).

${ }^{b}$ Value is significantly greater $(P<0.001)$ than controls.

60 days of age and in two of three progesterone-treated gilts at 150 days of age were below assay sensitivity $\left(10 \mathrm{pg} \mathrm{ml}^{-1}\right)$. The amounts of PGF in progesterone-treated gilts aged 90 days and 120 days were compared using one-way analysis of variance.

\section{Results}

\section{Serum}

Analyses of the concentrations of progesterone and oestradiol in serum collected after treatments indicated that progesterone treatment increased $(P<0.001)$ the concentration of progesterone in serum 26.2 times compared with that in control gilts (Table 1 ). No effects of age on the concentrations of progesterone were observed $(P<0.40)$. Oestradiol was not $(P>0.10)$ affected by treatment with progesterone or by age. One gilt in the control group aged 120 days displayed a very high concentration of oestradiol, which caused the large mean value for that group. However, the ovaries of this gilt contained only small follicles ( $<3 \mathrm{~mm}$ diameter), and the uterine responses observed for this gilt were similar to those of other gilts undergoing the same treatment. In fact, all data contributed by this gilt were intermediate between that from the other two gilts in this treatment group. Therefore, data from this gilt do not distort treatment means and were included in statistical analyses.

\section{Uterine wet mass}

An interaction between age and progesterone treatment $(P<0.001)$ was observed with respect to uterine wet mass because the mass of the uterus was not affected by treating 20-day-old gilts with progesterone but was increased by treating gilts in the other age groups with progesterone (Fig. 1a). Uterine wet masss in gilts aged 60, 90, 120 and 150 days increased in response to progesterone by factors of $4.5,3.8,4.0$, and 4.8 , respectively.

\section{Total liminal protein}

Progesterone treatment increased $(P<0.01)$ the amount of TLP by factors of $1.8,6.2,6.9$, and 4.4 in the uterine flushes collected from gilts aged $60,90,120$ and 150 days, respectively (Fig. Ib). TLP in the 20-day-old gilts did not $(P>0.6)$ respond to progesterone treatment and the amount of TLP in these gilts was less $(P<0.5)$ than in older gilts.

\section{Retinol binding protein and uteroferrin}

The amounts of RBP and UF in uterine flushings are shown (Fig. 2). For initial analyses, data were calculated in two ways: as the total amount of RBP or UF recovered per uterine horn; or as the amount of the protein per $\mu \mathrm{g}$ TLP. Responses observed were similar using both calculation methods and the amount of RBP or UF per $\mu \mathrm{g}$ TLP is shown. An interaction between age and progesterone treatment $(P<0.001)$ was observed because progesterone did not $(P>0.1)$ affect the amount of uterine luminal RBP in 20-day-old and 60-day-old gilts. Progesterone treatment increased the amount of RBP by factors of $14.8,29.7$ and $68.1(P<0.01)$ in gilts aged 90, 120 and 150 days, respectively (Fig. 2a). Western blot analysis confirmed that RBP was of the expected size (approximately $20 \mathrm{kDa}$ ) and that the treatment with progesterone had increased the concentration of RBP in the uterine flushings by 90 days of age (data not shown).

An interaction between age and progesterone treatment $(P<0.001)$ revealed that UF did not increase in response to progesterone in 20-day-old and 60-day-old gilts, whereas gilts aged 90,120 and 150 days responded to progesterone with increased $(P<0.001)$ amounts of UF $(18.3,14.4$, and 56.6 times the amount in control gilts, respectively; Fig. 2b). Western blot analysis confirmed the presence of protein reacting with the UF antibody of the expected size $(35 \mathrm{kDa})$ and that treatment with progesterone first appeared to enhance the concentrations of UF in the uterine flushes in 90-day-old gilts (data not shown).

\section{Prostaglandins}

Prostaglandins were not assayed in uterine flushes of 20-day-old gilts because the limited number of samples obtained from these gilts was used for other assays. An interaction between age and progesterone $(P<0.01)$ showed that PGE was not $(P<0.1)$ increased by progesterone in 60 -day-old gilts but increased $(P<0.001$ ) in older gilts (Fig. 2 c). The greatest response occurred in progesterone-treated gilts 

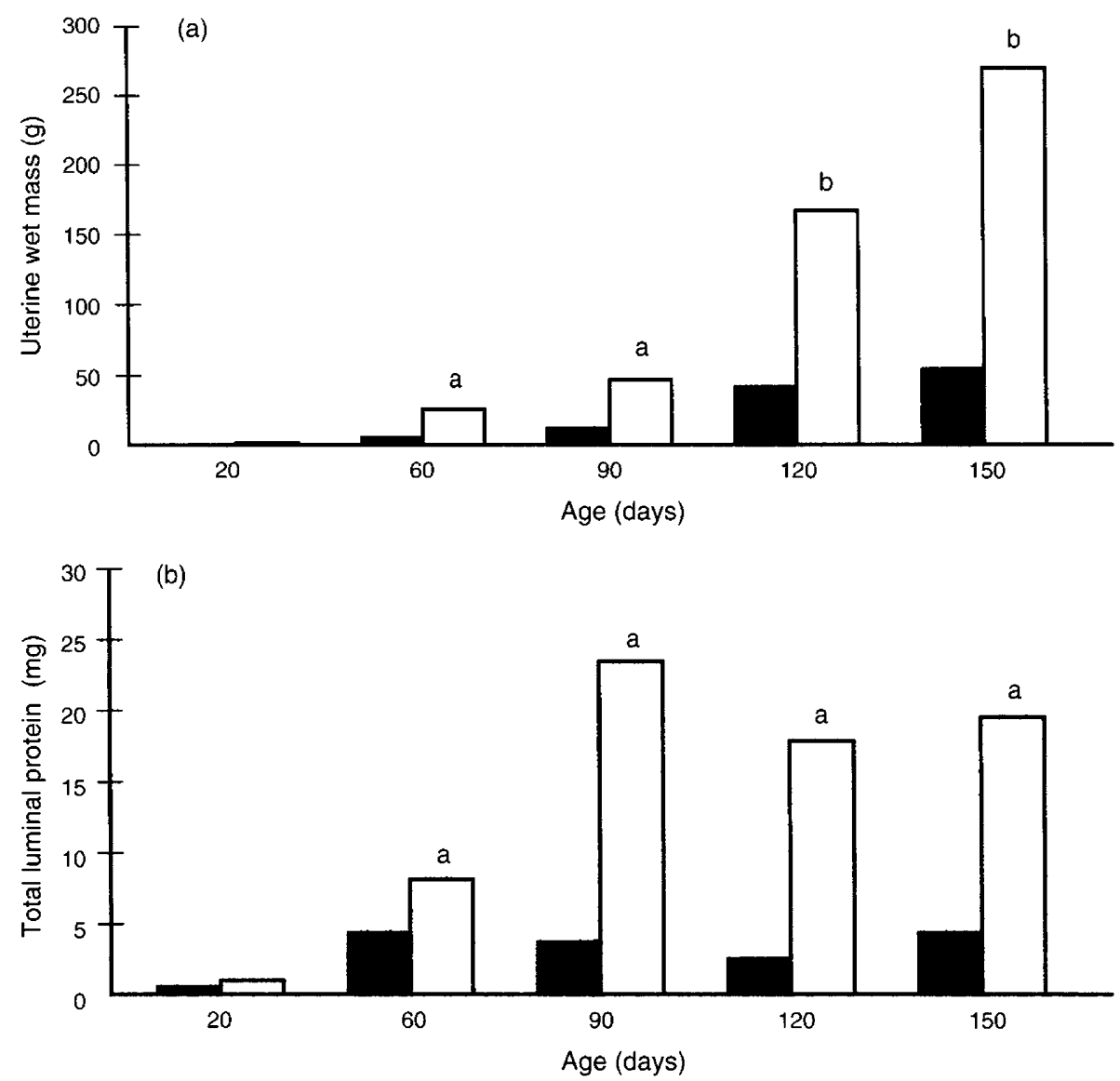

Fig. 1. (a) Uterine wet mass and (b) total luminal protein (TLP) in the uterus of progesterone-treated $(\square)$ and vehicle-treated ( $\boldsymbol{\square})$ gilts. An interaction between age and progesterone treatment $(P<0.001)$ was detected for uterine mass. ${ }^{\text {ab}}$ Values are significantly greater $(P<0.05)$ than those in vehicle-treated gilts; values for progesterone-treated gilts with different superscripts differ significantly from each other $\{P<0.05\}$.

receiving hysterectomies at 120 days of age and flushings from their uteri yielded PGE amounts greater $(P<0.05)$ than PGE from 90- and 150-day-old progesterone-treated gilts.

The concentration of PGF in flushings was much less than that of PGE, and none of the samples collected from the uteri of 60-day-old gilts contained detectable amounts of PGF $\left(<10 \mathrm{pg} \mathrm{ml}^{-1}\right.$ ). Furthermore, PGF could not be detected in any of the uterine luminal flushings from older control gilts, but PGF in the luminal flushings from progesterone-treated gilts increased $(P=0.07)$ from $12 \pm 13.3 \mathrm{ng}$ per uterine horn at 90 days of age to $104 \pm 13.3 \mathrm{ng}$ per uterine horn at 120 days of age. However, at 150 days of age, only one out of three samples of uterine flushings from progesterone-treated gilts displayed detectable amounts of PGF (5.5 ng per uterine horn).

\section{Discussion}

In this study, the circulating concentration of progesterone was increased $24 \mathrm{~h}$ after injection with progesterone. The apparent fluctuations in the concentrations of this hormone in gilts of different ages (Table 1) were not statistically significant. Ellicott and Dziuk (1973) concluded that a minimum concentration of
$4 \mathrm{ng}$ progesterone $\mathrm{ml}^{-1}$ was necessary to maintain pregnancy in pigs. With the exception of one 20-day-old gilt, serum from all progesterone-treated gilts contained progesterone at concentrations $>4 \mathrm{ng} \mathrm{ml}^{-1}$. (The serum of an exceptional gilt contained $3.4 \mathrm{ng}$ progesterone $\mathrm{ml}^{-1}$.) Gilts were exposed to concentrations of progesterone that are adequate to maintain pregnancy and, therefore, presumably adequate to stimulate the other uterine secretions necessary during pregnancy maintenance.

In pigs, treatment with progesterone during the first 2 weeks of neonatal life does not affect uterine histology (Vallet et al., 1995). Data from the present study indicate that progesterone affects uterine mass when treatment for 14 days began when the gilt was 46 days old but not when progesterone treatment began 6 days after farrowing. In contrast, treatment with oestradiol during the first weeks of neonatal life dramatically affects uterine morphology and histology (Spencer et al., 1993b; Vallet et al., 1995). Neonatal oestradiol administration has been associated with changes in protein secretion (Spencer et al., 1993b) and reduced embryo survival in gilts that subsequently became pregnant during the second oestrus after puberty (Bartol et al., 1993). Thus, even though the uterus develops independently of ovarian influences during the first 

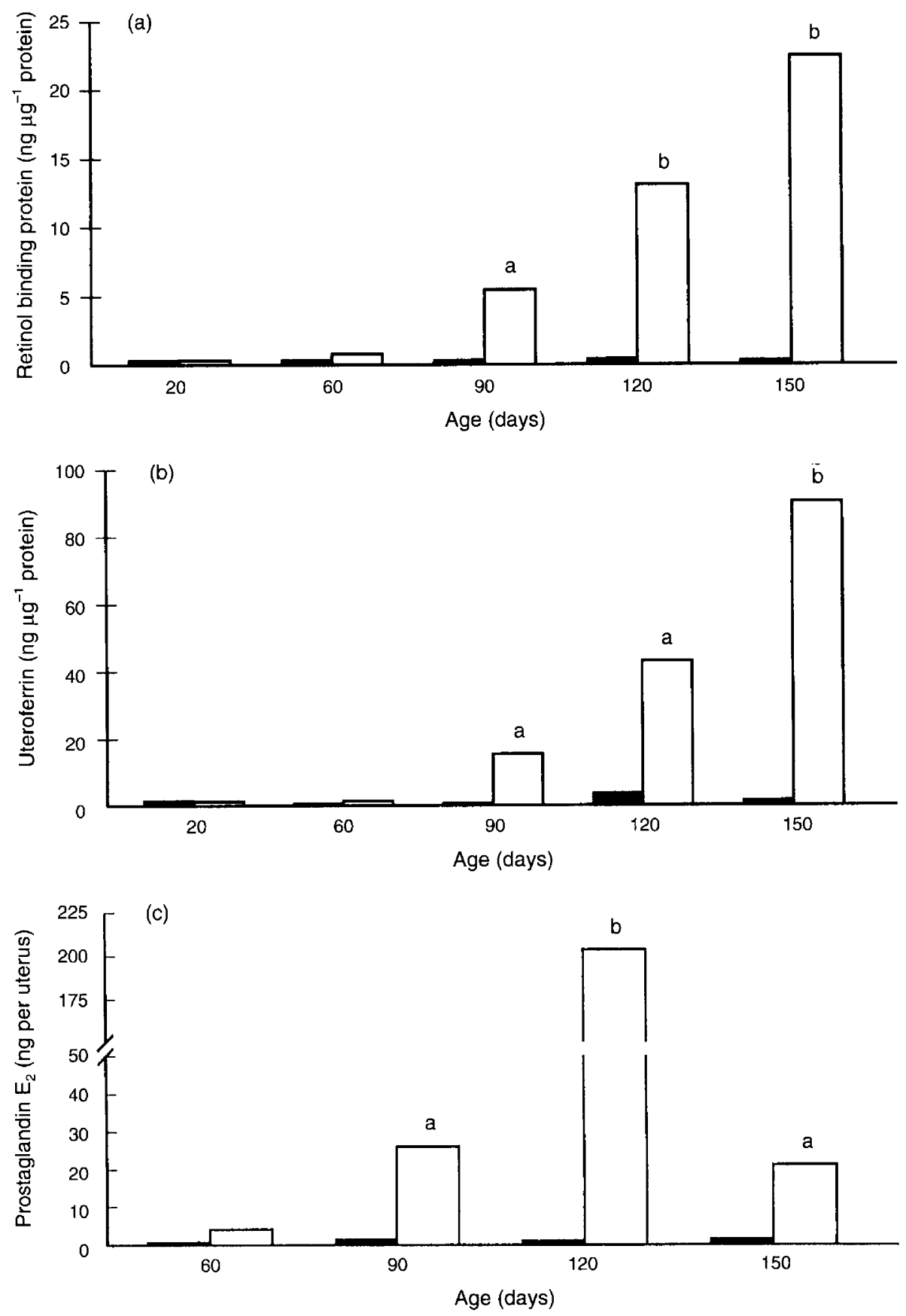

Fig. 2. The effect of progesterone on (a) retinol binding protein (RBP), (b) uteroferrin (UF) and (c) prostaglandin E (PGE) in uterine flushings from progesterone-treated ( $\square$ ) and vehicle-treated ( $\square$ ) gilts. RBP and UF are expressed as ng per $\mu$ g protein in the flushings. An interaction between age and progesterone treatment $(P<0.001)$ was detected for RBP and UF. ${ }^{\text {ab }}$ Values are significantly greater $(P<0.05)$ than those in vehicle-treatment gilts; values for progesterone-treated gilts with different superscripts differ significantly from each other $(P<0.05)$.

60 days of life ( $\mathrm{Wu}$ and Dziuk, 1988), it is responsive to exogenous steroids at earlier stages.

In the present study, progesterone and oestradiol were detectable in the serum of control gilts at 20 days of age and were most likely of adrenal origin because the ovaries have not developed steroidogenic capacity at this age (Elsaesser, 1982; Christenson et al., 1985). Studies in the mouse (Ogasawara et al., 1983) showed that early uterine histogenesis proceeds normally in neonatal mice from which both adrenal glands and ovaries have been removed. Therefore, development of the neonatal uterus appears to be developmentally controlled and steroid-independent.

The results of the present investigation show that the responsiveness of the prepubertal uterus to progesterone 
develops well before the time of spontaneous puberty. Furthermore, the timing of the onset of response to progesterone indicates different age-related controls for each response. For example, an increase in uterine mass in response to progesterone was first evident at 60 days of age and increased with advancing age. When considered as an increase with respect to control gilts, this response was constant at approximately fourfold in gilts 60 days old and older. Total luminal protein also was not affected by progesterone at 20 days of age but was increased at 60 days of age after treatment with progesterone for 14 days. The magnitude of the response was similar in gilts aged 90-150 days. Compared with TLP, the secretory proteins RBP and UF were first induced by progesterone treatment in 90-day-old gilts, with an increasing response of these proteins in gilts up to 150 days of age. Interpretation of the onset of the response by RBP and UF secretion in this experiment is limited by the 30-day interval between 60-day-old and 90-day-old gilts. Both proteins demonstrated an increasing response to progesterone treatment with advancing age. Perhaps a more important biological issue is the time at which uterine secretions are adequate to support the conceptuses. Pregnancies can first be initiated, although usually not maintained, in gilts at 90-120 days of age. In the light of results presented here, it may be that the uterine secretory response first approximates that of adult females at about that age. For comparison, we observed the amounts of UF and RBP in the uterine flushings of sows and gilts on day 11 of pregnancy to be $29.3 \pm 5$ and $15.1 \pm 5 \mathrm{ng} \mu \mathrm{g}^{-1}$ protein, respectively (P. G. Groothuis, unpublished). Similar values were observed for 120-day-old gilts after treatment with progesterone for 14 days (Fig. 2a,b).

The response of prostaglandins to progesterone treatment demonstrated yet another pattern: the secretion of PGE and PGF increased from 60 to 120 days of age but at 150 days of age, it decreased to below the amounts detected in 90-day-old gilts. The pattern of response of prostaglandins may reflect the regulation of cell proliferation (Orlicky et al., 1986) and the prostaglandins that were detected in this study could have been cellular byproducts of tissues undergoing cellular remodelling, as proposed by Giesert et al. (1986) for the elongating pig blastocyst. Therefore, the presence of uterine luminal prostaglandins may reflect the structural development of the uterus and the decline in their response to progesterone between 120 and 150 days of age may be correlated with less dramatic cell and tissue remodelling in older gilts. However, these associations have not been tested in the prepubertal uterus.

These observations provide evidence for differential developmental regulation of responsiveness to progesterone. The present study did not address the possibility that oestrogen priming before treatment with progesterone might affect the age-related patterns of response. However, since the concentrations of oestradiol in control gilts were similar from 20 to 150 days of age, oestrogen priming is probably not responsible for the age-related patterns of responsiveness to progesterone observed in this study.

The developmental stage at which a particular response is acquired could provide a model for studying the regulation of that response. Thus, the increase in uterine mass might be studied at 60 days of age, before secretory responses occur.
The uterine growth response to progesterone may be important because each pig fetus must have an initial uterine length of at least $36 \mathrm{~cm}$ to survive and develop (Wu et al., 1987, 1989). Although untested so far, increasing prepubertal uterine growth might improve the number of pigs per litter or the litter birth mass, or both. Treatment with progesterone at an early age might accomplish this, although further studies are needed to investigate how reproductive efficiency is affected if this treatment is performed before first oestrus. Sananes et al. (1980) demonstrated that administration of progesterone to rats 7-9 days after birth impaired the capacity of the adult female to develop deciduomata. However, differences exist between species in this respect because progestins given to neonates decrease uterine gland formation in sheep (Bartol et al., 1988) and impair epithelial proliferation in mice (Bigsby and Cunha, 1985), effects not observed in progesterone-treated neonatal pigs (Vallet et al., 1995). It seems likely that progesterone affects uterine growth partly through other effector molecules. In summary, an understanding of the uterine growth induced by progesterone should provide useful information for researchers attempting to increase uterine size and capacity.

The authors thank N. R. Mason (Eli Lilly, Indianapolis, IN) and W. W. Thatcher (University of Florida, Gainesville, FL) for kindly supplying the antisera for PGE and PGF, respectively. Contribution No. 97-20-J from the Kansas Agricultural Experiment Station and R-05665 from the Florida Agriculture Experiment Station.

\section{References}

Bal FS and Getty R (1970) Postnatal growth of the swine uterus from birth to six months Growth 34 15-30

Bartol FF, Wiley AA, Coleman DA, Wolfe DF and Riddell MG (1988) Ovine uterine morphogenesis: effects of age and progestin administration and withdrawal on neonatal endometrial development and DNA synthesis Journal of Animal Science 66 3000-3009

Bartol FF, Wiley AA, Spencer TE, Vallet JL and Christenson RK (1993) Early uterine development in pigs Journal of Reproduction and Fertility Supplement 48 99-116

Bigsby RM and Cunha GR (1985) Effects of progestins and glucocorticoids on deoxyribonucleic acid synthesis in the uterus of the neonatal mouse Endocrinology 117 2520-2526

Blair RM, Coughlin CM, Minton JE and Davis DL (1993) Embryonic survival and variation in embryonic development in gilts and primiparous sows on day 11 of gestation Journal of Reproduction and Fertility 101 167-173

Casida LE (1935) Prepubertal development of the pig ovary and its relation to stimulation with gonadotrophic hormones Anatomical Record 61 389-396

Christenson RK, Ford JJ and Redmer DA (1985) Maturation of ovarian follicles in the prepubertal gilt journal of Reproduction and Fertility Supplement 33 21-36

Danet-Desnoyers G, Wetzels C, and Thatcher WW (1994) Natural and recombinant bovine interferon regulate basal and oxytocin-induced secretion of prostaglandins $\mathrm{F}_{2 \pi}$ and $\mathrm{E}_{2}$ by epithelial and stromal cells in the endometrium Reproduction, Fertility and Development 6 193-202

Dziuk PJ and Gehlbach GD (1966) Induction of ovulation and fertilization in the immature gilt Journal of Animal Science 25 410-413

Ellicottt AR and Dziuk PJ (1973) Minimum daily dose of progesterone and plasma concentration for maintenance of pregnancy in ovariectomized gilts Biology of Reproduction 9 300-304

Ellicott AR, Dziuk PJ and Polge C (1973) Maintenance of pregnancy in prepubertal gilts Journal of Animal Science 37 971-973

Elsaesser F (1982) Endocrine control of sexual maturation in the female pig and sexual differentiation of the stimulatory oestrogen feedback mechanism. In Control of Pig Reproduction Pp 93-116 Eds Cole DJA and Foxcroft GR. Butterworths, London 
Fertel R, Yetiv JZ, Coleman MA, Greenwald IE and Blanchine JR (1981) Formation of antibodies to prostaglandins in the yolk of eggs Biochemical and Biophysical Research Communication 102 1028-1033

Giesert RD, Rasby RJ, Minton JE and Wettemann RP (1986) Role of prostaglandins in development of porcine blastocysts Prostaglandins 31 191-204

Lowry OH, Rosebrough NJ, Farr AL and Randall RJ (1951) Protein measurement with the Folin-phenol reagent Journal of Biology and Chemistry 193 265-275

Murray FA and Grifo AP (1976) Development of capacity to secrete progesterone-induced protein by the porcine uterus Biology of Reproduction 15 620-625

Neville WJ, Scanlon PF and MacPherson JW (1971) Maintenance of pregnancy in prepubertal gilts Journal of Animal Science 33262 (Abstract)

Ogasawara Y, Okamoto S, Kitamura Y and Matsumoto K (1983) Proliferative patterns of uterine cells from birth to adulthood in intact, neonatally castrated and/or adrenalectomized mice, assayed by incorporation of [ ${ }^{125}$ I]-iododeoxyuridine Endocrinology 113 582-587

Orlicky DJ, Lieberman R and Gerschenson LE (1986) Prostaglandin $F_{2 a}$ and $E_{1}$ regulation of proliferation in primary cultures of rabbit endometrial cells Joumal of Cellular Physiology 127 55-60

Roberts RM and Bazer FW (1988) The function of uterine secretions journal of Reproduction and Fertility 82 875-892

Rosenkrans CF, Jr, Paria BC, Davis DL and Milliken G (1990) In vitro synthesis of prostaglandin $\mathrm{E}$ and $\mathrm{F}_{2 a}$ by pig endometrium in the presence of estradiol, catechol estrogen and ascorbic acid Journal of Animal Science 68 435-443

Sananes N, Baulieu EE and LeGascogne C (1980) Treatment of neonatal rats with progesterone aiters the capacity of the uterus to form deciduomata Journal of Reproduction and Fertility 58 271-273

SAS (1982) SAS User's Guide Statistics SAS Institute, Cary, NC

Schnurrbusch U and Erices J (1979) Histomorphological alterations in the uterus of gilts during the first three estrous cycles Archiv fur Experimentelle Veterinarmedizin 33 527-546
Segal DH and Baker RD (1973) Maintenance of corpora lutea in prepubertal gilts Journal of Animal Science 37 762-767

Shaw GA, McDonald BE and Baker RD (1970) Utero-ovarian interrelationships in prepubertal and gonadotrophic treated gilts Canadian Journal of Animal Science 50 185-190

Simmen RCM, Baumbach GA and Roberts RM (1988) Molecular cloning and temporal expression during pregnancy of the messenger ribonucleic acid encoding uteroferrin, a progesterone-induced secretory protein Molecular Endocrinology 2 253-262

Spencer TE, Bartol FF, Wiley AA, Coleman DA and Wolfe DF (1993a) Neonatal porcine endometrial development involves coordinated changes in DNA synthesis, glycosaminoglycan distribution, and ${ }^{3} \mathrm{H}$-glucosamine labeling Biology of Reproduction 48 729-740

Spencer TE, Wiley AA and Bartol FF (1993b) Neonatal age and period of estrogen exposure affect porcine uterine growth, morphogenesis, and protein synthesis Biology of Reproduction 48 741-751

Vallet JL (1994) Technical note: radioimmunoassay for porcine retinol binding protein Journal of Animal Science 72 2449-2454

Vallet JL, Christenson RK, Bartol FF and Wiley AA (1995) Effect of retinyl palmitate, progesterone, oestradiol, and tamoxifen treatment on secretion of a retinol binding protein-like protein during uterine gland development in neonatal swine Journal of Reproduction and Fertility 103 189-197

Wu MC and Dziuk PJ (1988) Ovarian influence on uterine growth in prepubertal gilts Journal of Animal Science 66 2893-2898

Wu MC, Hentzel MD and Dziuk PJ (1987) Relationships between uterine length and number of fetuses and prenatal mortality in pigs Journal of Animal Science $65762-770$

Wu MC, Chen ZY, Jarrell VL and Dziuk PJ (1989) Effect of initial length of uterus per embryo on fetal survival and development in the pig Journal of Animal Science 67 1767-1772 